\title{
Time lapse photography with two different camera systems for in situ observation of the bivalve Diplodon chilensis (Gray, 1828) in a southern Chilean lake
}

\section{Fotografía en lapso de tiempo con dos sistemas de cámaras diferentes para la observación in situ del bivalvo Diplodon chilensis (Gray, 1828) en un lago del sur de Chile}

\author{
Gesche Kohlberg*1 $^{* 1}$, Anne Herbst ${ }^{1}$, Gerd Niedzwiedz ${ }^{1}$, Stefan Woelfl ${ }^{2}$, Jorge Nimptsch ${ }^{2}$ \& Dirk \\ SCHORIES ${ }^{1,3}$ \\ ${ }^{1}$ Universität Rostock, Institut für Biowissenschaften, Albert-Einstein-Straße 3,18059 Rostock, Germany. \\ ${ }^{2}$ Universidad Austral de Chile, Instituto de Ciencias Marinas y Limnológicas, Facultad de Ciencias, Valdivia, Chile. \\ ${ }^{3}$ Forschungszentrum Jülich, Projektträger Jülich, Forschungszentrum Jülich GmbH, Godesberger Allee 105-107, 53175 Bonn, \\ Germany. \\ *geschekohlberg@gmx.de
}

\begin{abstract}
We compared the validity of two low cost camera systems to analyze the filtration activity of Diplodon chilensis (Gray, 1828), the most common freshwater bivalve in southern Chile, by using time lapse photography. One camera system (Nikon D300) was connected with an external flash, whereas the other system (GoPro Hero 3+) contained a permanent video light source. Size change of the exhalant siphon area (ESA) of Diplodon individuals was used to track activity changes over time. The siphon of $D$. chilensis was completely closed for $3.4 \% \pm 5.2 \%$ (mean $\pm \mathrm{SD}$ ) of the recording time and it shows a nearly completely opened siphon for $42.7 \% \pm 22.9 \%$ of the recording time. The mean siphon opening was $68.3 \% \pm 26.5 \%$ of its potential opening area. Although a red filter was placed in front of the video light source, the mobile fauna, especially Aegla abtao (Schmitt, 1942) and unidentified small fishes were highly attracted by the permanent light. We conclude that both low cost cameras are very suitable for in situ time lapse observation of freshwater clams since both deliver good image quality. However, special attention should be given to the light source since permanent light attracts animals including predators which might change filtration activity of $D$. chilensis.
\end{abstract}

KEYWORDS: camera system comparison, Diplodon chilensis, exhalant siphon area, time lapse photography.

\section{RESUMEN}

Comparamos la validez de dos sistemas de cámara de bajo costo para analizar la actividad de filtración de Diplodon chilensis (Gray, 1828), el bivalvo de agua dulce más común en el Sur de Chile, usando fotografía de lapso de tiempo. Un sistema de cámara (Nikon D300) se conectó con un flash externo, mientras que el otro sistema (GoPro Hero 3+) contenía una fuente de luz de vídeo permanente. El sifón de $D$. chilensis fue completamente cerrado por $3.4 \% \pm 5.2 \%$ (media \pm desviación estándar) del tiempo de grabación y muestra un sifón casi completamente abierto durante $42.7 \% \pm 22.9 \%$ del tiempo de grabación. La apertura media del sifón fue de $68.3 \% \pm 26.5 \%$ de su área de apertura potencial. Aunque un filtro rojo se colocó frente a la fuente de luz de vídeo, la fauna móvil, especialmente Aegla abtao (Schmitt, 1942) y los peces pequeños no identificados, fueron fuertemente atraídos por la luz permanente. Concluimos que ambas cámaras son adecuadas para la observación in situ de fotografía en lapso de tiempo de las almejas de agua dulce, ya que ambas ofrecen una buena calidad de imagen. Sin embargo, se debe prestar especial atención a la fuente de luz, ya que la luz permanente atrae a los animales, incluidos los depredadores, que podrían cambiar la actividad de filtración de $D$. chilensis.

Palabras clave: área de sifón exhalante, comparación de sistemas de cámaras, Diplodon chilensis, fotografía en lapso de tiempo. 


\section{INTRODUCTION}

The first time lapse studies go back to the sheer observation of organisms in defined time intervals. This has been applied at the early beginning in a variety of scientific fields by direct microscopic observations (Carey \& Pettengill 1967), in aquaria and in situ. Since the 1970s also self-contained underwater time lapse cameras for long term observations ( $>1$ week) were used and placed by divers in the area of interest (Fedra \& Machan 1979). The technical conditions were already developed in the 1960s (Mitchell 1967) and applied by Kenneth Read in 1967 who recorded time lapse series with a video camera designed by Harold E. Edgerton (Marx 1990). Due to the rapid development of photo and camera techniques which provide time lapse modes in many customary photo and video cameras, nowadays this technique is often used to visualize slow motion processes (Beuchelm et al. 2010).

Several field studies, which did not use automatic recording devices, underestimated the true activity of slow moving animals like sea stars or gastropods, because the time interval between two observations was too long. Displacement of individuals instead of movement was measured (Barahona \& Navarrete 2010). Time lapse photography constitutes the link to other benthic studies that deal only with the analysis of the community which structure is often only defined by animals' and plants' abundance and coverage (Beuchelm et al. 2010) and do not consider short term variations. Stachowitsch et al. (2007) simulated oxygen depletion and anoxia affecting a benthos community and documented the effects with the help of time lapse photography. Lampitt et al. (1984) used this technique to study deep sea benthos, while Kohler (1984) analyzed insect larvae in rivers. Several aspects of mussels were studied by time lapse photography. Sawyer et al. (2009) investigated predator-prey interactions of a sublittoral mussel bed in the Gulf of Trieste (Northern Adriatic).

In this work this noninvasive technique is used to measure filtration activities of the freshwater clam Diplodon chilensis under field conditions. It is the most common fresh water mussel on both sides of the southern Andes, South America and occurs in Chile between $30^{\circ} 28^{\prime} \mathrm{S}$ and 46 37' S (Parada et al. 2007; Valdovinos \& Pedreros 2007). Individuals can reach a shell length of $10 \mathrm{~cm}$, an age of around 90 years and live semi-buried (Fig. 1) as well in deep as shallow waters (Lara \& Parada 2008; Soldati 2009). Its habitat ranges from sandy, sandy-pebbly to muddy sediments reaching population densities of 10 ind. $\mathrm{m}^{-2}$ in sandy substrates and 361 ind. $\mathrm{m}^{-2}$ in muddy sediments (Lara \& Parada 1988). D. chilensis has a mixed feeding based on phytoplankton, phytobenthos and organic matter existent in the plankton and benthos (Lara et al. 2002). It shows a significant reduction in its geographic ranges and is considered to be a threatened species in many Chilean lakes
(Parada \& Peredo 2005; Valdovinos \& Pedreros 2007). Soto \& Mena (1999) measured the ability of D. chilensis to filter algae and clear the water column of particulates and dissolved nutrients associated with salmon farms. They concluded that $D$. chilensis may have a significant filtering effect on lakes due to their high filtration rate of about 1.3 $1 * \mathrm{~h}^{-1}$ ind $^{-1}$ and their high density in Southern Chilean lakes (50-200 ind.* $\mathrm{m}^{-2}$ ). Ecological importance of freshwater mussels in general and specifically $D$. chilensis relies in their importance of ecological processes such as biofiltration of suspended particles and phytoplankton reducing nuisance cyanobacteria ameliorating effects of eutrophication (Sabatini et al. 2011; Atkinson et al. 2013); nutrient cycling - nutrient storage (Vaughn 2018), alleviating nutrient limitation and changing algae communities in riverine ecosystems (Atkinson et al. 2013); providing habitat for other organisms and supporting food-webs providing nutrients and energy for other species (Vaughn 2018).

However, the measuring of the filtration activity of mussels has been discussed controversially for many years (Bayne 1998; Jørgensen 1996; Riisgård 2001). Newell et al. (2001) found the exhalant siphon area (ESA) to be a good remote sensing of feeding rates. Valve opening and opening of the exhalant siphon aperture may be uncoupled. This can be observed when animals are exposed to elevated current velocities, declining salinities (Newell et al. 2001; Davenport 1979) or elevated levels of copper and other pollutants (Manley 1983; Kramer et al. 1989). Due to the need for respiration the bivalves hold the valves open although pumping through the siphon and therefore feeding is interrupted which also involves the control of exhalent siphon activity as discussed by Manley (1983).

Here we present first results of filtration activity of $D$. chilensis during night using the exhalant siphon aperture (ESA) as a proxy of the measurement of filtration activity. It was also studied whether the filtration activity changes from day to night time or remains constant over time. Measuring ESA during night time with time lapse techniques requires the usage of an artificial light source, therefore this study also focuses on the technical aspects of this procedure. For that, we compared two different camera systems, one equipped with a permanent light source and another with an external flash.

\section{MATERIAL AND METHODS}

STUDY SITE

All in situ experiments were conducted at Lake Panguipulli, which is located in the Araucanian Lake district, southern Chile (Fig. 2) in March 2015 and March 2016, late austral summer. The lake is oligotrophic with a Secchi depth of $9.8 \mathrm{~m}-17.0 \mathrm{~m}$ (Woelfl, 2007), has an area of $116 \mathrm{~km}^{2}$, a maximum length of about $30 \mathrm{~km}$ and a maximum depth of 
$268 \mathrm{~m}$. Two time lapse cameras were installed in the bay of Rucatrehua at the eastern lakeside in the vicinity of a beach (39 $45^{\prime} 05^{\prime}$ ' S and $72^{\circ} 09^{\prime} 45^{\prime \prime} \mathrm{W}$ ) (Fig. 2), in $30 \mathrm{~m}$ distance to the shore at a water depth of about $10 \mathrm{~m}$. At this depth the time lapse recordings were performed. Water temperature at $10 \mathrm{~m}$ depth was about $20{ }^{\circ} \mathrm{C}$ with high visibility. Sediment was predominantly composed by gravel, coarse to fine sand and occasionally deadwood (Fig. 1).

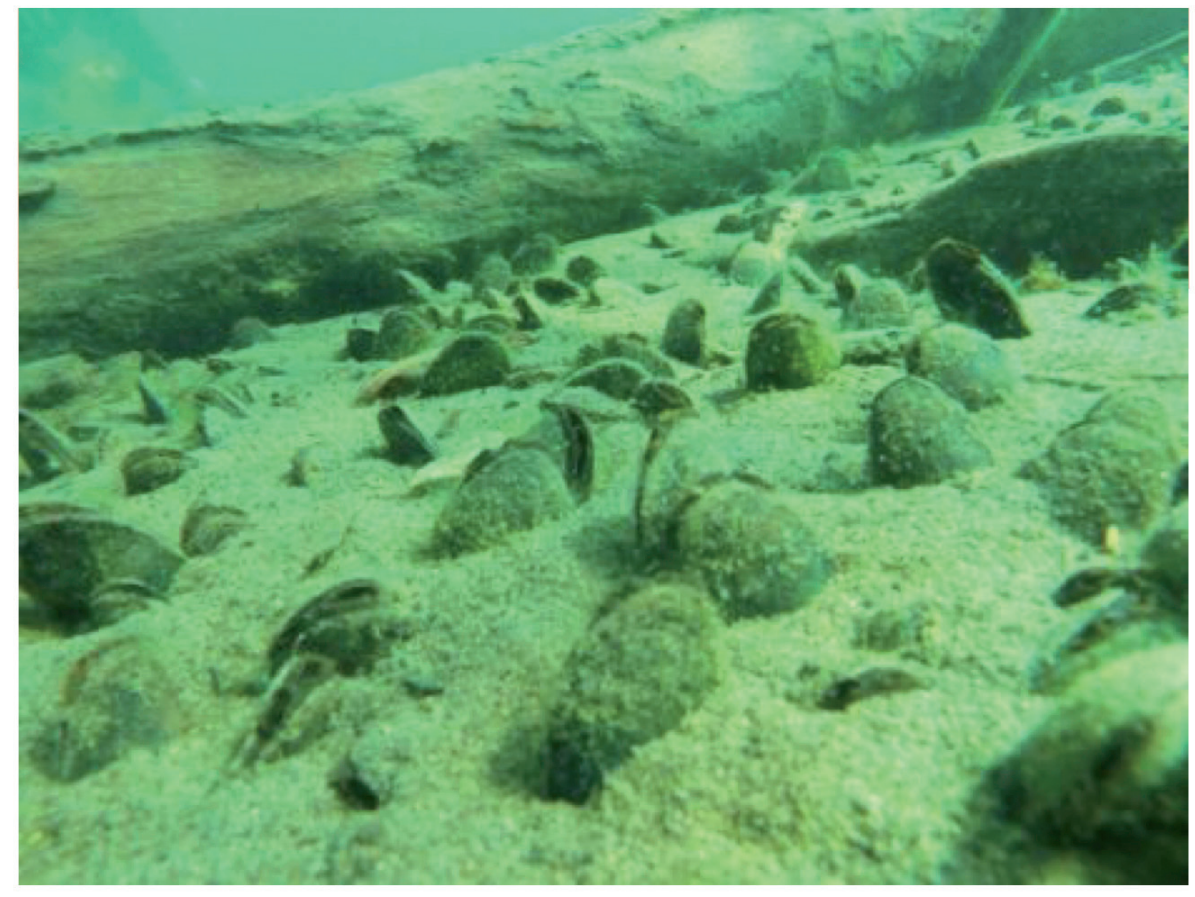

Figure 1. Sea bed at Panguipulli Lake with semi-buried and filtrating individuals of $D$. chilensis. / Sedimento en el lago Panguipulli con individuos semi-enterrados y filtrando de $D$. chilensis.

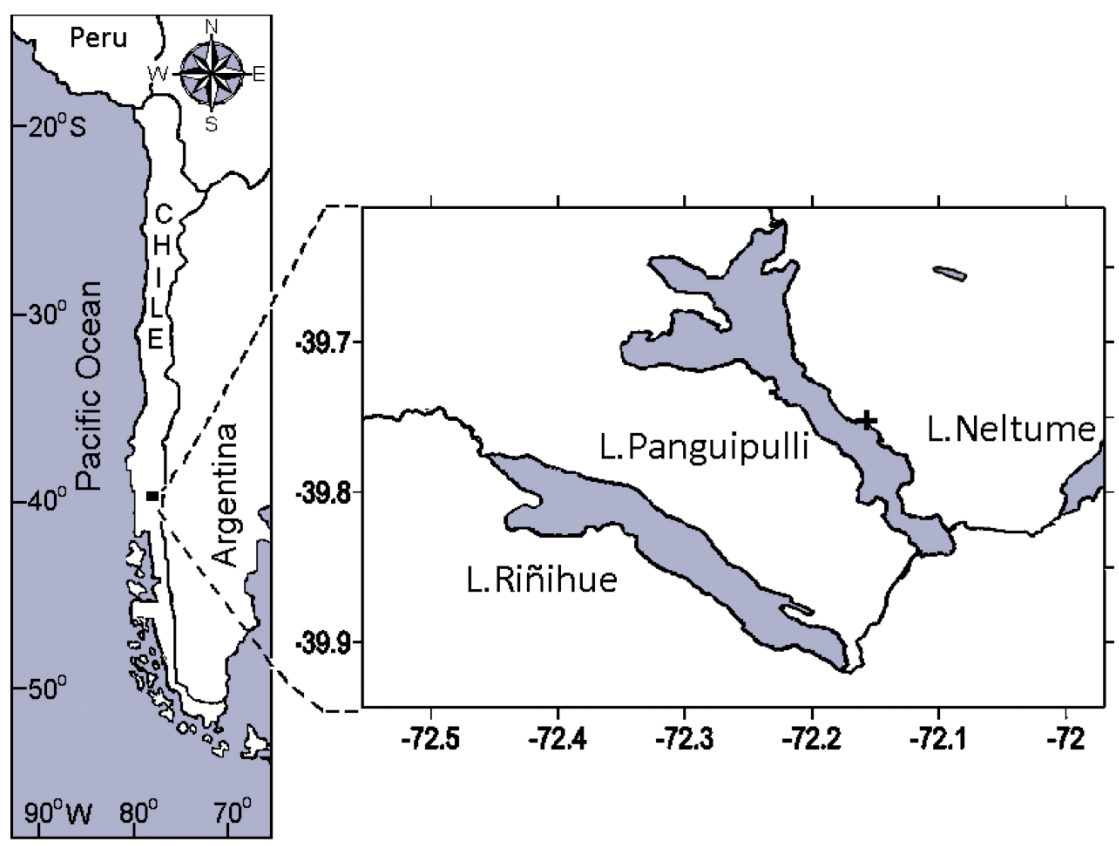

Figure 2. Map of the study site Rucatrehua (black cross) at Lake Panguipulli, Lake Region, Southern Chile. / Mapa del sitio de estudio (cruz negra) en el lago Panguipulli, Región de los Lagos, Sur de Chile. 
TECHNICAL EQUIPMENT

For the observation of the bivalves' filtration activity time lapse photography was applied using two different camera systems (Table 1, Fig. 3). One camera was a Nikon D300 in an underwater housing equipped with a Subtronic Pro160 flash connected to an external battery pack (capacity 9Ah). The Nikon camera can take pictures with a resolution of 12 megapixels. At a rate of one image per every 2 minutes the cameras' battery (capacity $1600 \mathrm{mAh}$ ) lasts for approximately $13 \mathrm{~h}$, if the monitor and the autofocus are switched off. Images were taken at a shutter speed of 1/80 sec and with ISO 200. For every image the external flash was activated at a distance of $30 \mathrm{~cm}$ to the substrate at a flash intensity of $1 / 16$ (Fig. 3). The autofocus of the camera was switched off after the first image taken (1) to avoid fliggering of the image series and (2) to guarantee that the camera does not run out of the focus during night time. The camera itself weighs $925 \mathrm{~g}$, the underwater-housing made of corrosion-resistant aluminum approximately $2500 \mathrm{~g}$, the flash and the battery pack with $1920 \mathrm{~g}$ have to be added. The lenses are interchangeable, and the application depends on the work priorities and therefore the minimum focus distance varies but is minimum more or less $5 \mathrm{~cm}$ with a macro lens. In this study the distance between lens and mussels was about $40 \mathrm{~cm}$. The interval time can be chosen freely in the range from seconds over minutes to hours. The rack on which the Nikon camera is fixed has a defined area for quantitative estimations of mussel density and other epibenthic organisms.

TABLE 1. Technical features of the deployed camera systems Nikon D300 and GoPro Hero 3+ black edition. / Características técnicas de los sistemas de cámara desplegados Nikon D300 y GoPro Hero 3+ black edition.

\begin{tabular}{|c|c|c|}
\hline FEATURE & NIKON D300 & GoPro Hero 3+BLACK EDITION \\
\hline camera type & digital reflex camera & digital action camera \\
\hline image resolution & 12 megapixels & 12 megapixels \\
\hline size camera housing & $147 \times 114 \times 74 \mathrm{~mm}$ & $60 \times 40 \times 30 \mathrm{~mm}$ \\
\hline weight (without UW-housing) & $925 \mathrm{~g}$ & $156 \mathrm{~g}$ \\
\hline illumination & $\begin{array}{c}\text { external flash light, Subtronic } \\
\text { Pro160 }\end{array}$ & $\begin{array}{l}\text { external video light (permanent), } \\
\text { Caveman Spot }\end{array}$ \\
\hline lens & interchangeable & $\begin{array}{l}\text { wide angle (fix), external lens kits } \\
\text { are available }\end{array}$ \\
\hline image distortion & depending on the lens & yes \\
\hline minimum focus distance & depending on the lens, $\sim 5 \mathrm{~cm}$ & $\sim 18 \mathrm{~cm}$ \\
\hline interval time & $\begin{array}{l}\text { interval time completely } \\
\text { adjustable }\end{array}$ & $\begin{array}{l}\text { few given interval options }(0.5 \mathrm{sec} \text {, } \\
1 \mathrm{sec}, 2.5 \mathrm{sec}, 30 \mathrm{sec} \text { or } 60 \mathrm{sec})\end{array}$ \\
\hline depth of field & high & low \\
\hline autofocus & can be switched off & automatic; cannot be switched off \\
\hline display & internal or external & external display can be connected \\
\hline $\begin{array}{l}\text { operating time of the camera ( } 2 \\
\text { min interval) }\end{array}$ & $\begin{array}{c}13.5 \mathrm{~h} \text { (battery with } 1600 \mathrm{mAh} \\
\text { capacity; autofocus and } \\
\text { monitor switched off) }\end{array}$ & $\begin{array}{c}9.5 \mathrm{~h} \text { (with external battery; } \\
\text { 8AA x } 2600 \mathrm{mAh} \text {; external monitor } \\
\text { switched off) }\end{array}$ \\
\hline $\begin{array}{l}\text { manufacturer of underwater } \\
\text { housing }\end{array}$ & Sea \& Sea (UK) & Hugyfot (Belgium) \\
\hline waterproof UW-housing & $100 \mathrm{~m}$ & 200 m (with Hugyfot housing) \\
\hline
\end{tabular}


The second camera used was a GoPro Hero 3+ with an image resolution of 12 megapixels in a Hugyfot underwater housing (Fig. 3). Due to its non-interchangeable wide angle lens (Fig. 4), image distortion is noticeable at the edges of the photos. The camera and the housing weigh $2130 \mathrm{~g}$ whereof the camera itself weighs only $156 \mathrm{~g}$. In the Hugyfot housing an additional factory assembled battery for longer lasting recordings is integrated and facilitates operating times of up to $9.5 \mathrm{~h}$ in the time lapse modus of $1 \mathrm{image} / \mathrm{min}$, provided that the external screen is switched off. The battery pack has a capacity of 8AA x $2600 \mathrm{mAh}$. For accurate positioning and selection of the target area an external screen in an underwater housing (also Hugyfot) was connected to the camera. The GoPro System (camera, screen and lights) was installed on a low cost standard tripod, the camera facing towards the ground (Fig. 3). The distance between camera and ground was $65 \mathrm{~cm}$. For illumination during night two Caveman 3000 spots (manufacturer Natural Shine) were used, which shine continuously. To reduce the influence of permanent light on the fauna and flora a red filter permeable to wavelengths above $600 \mathrm{~nm}$ was put in front of the light. In the case of the Nikon and its flash, the battery capacity of the camera is the time limiting factor, whereas for the GoPro it is the battery of the video lights.

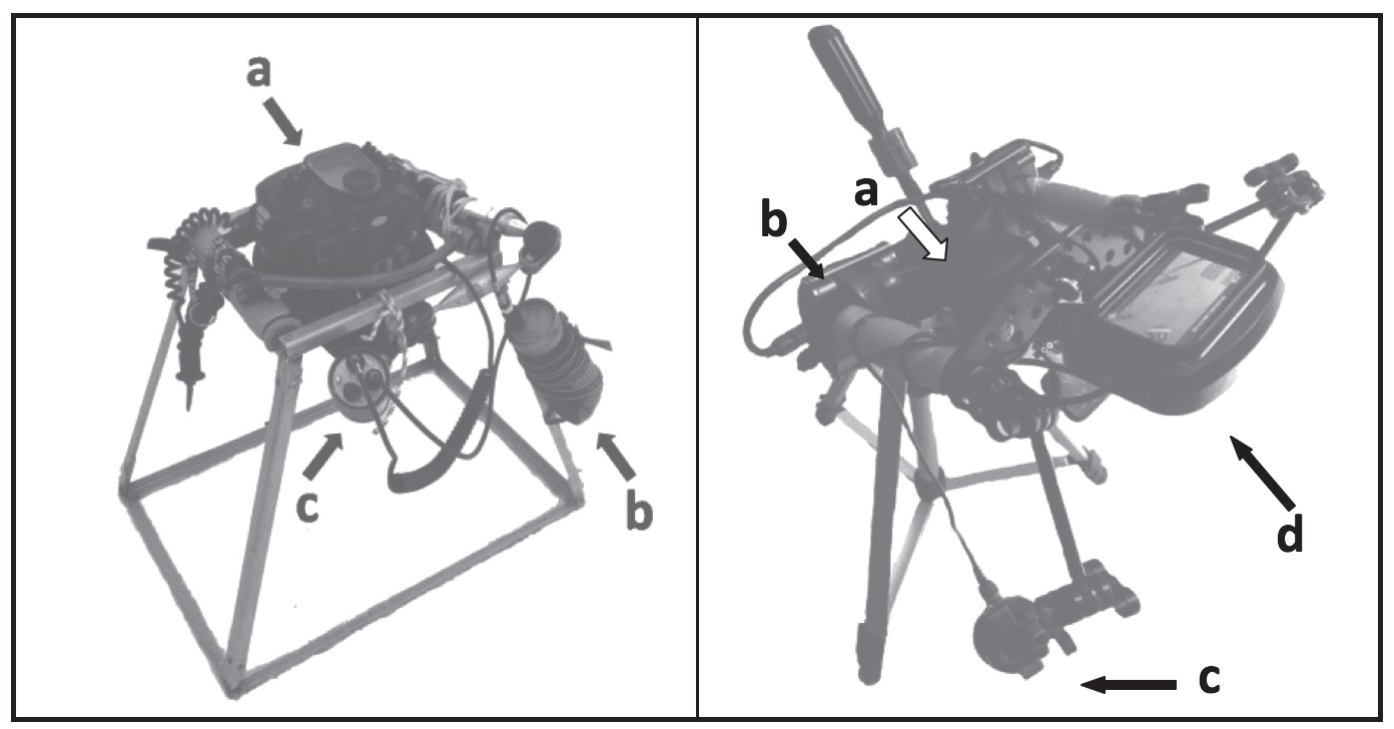

Figure 3. Nikon D300 (left) and GoPro 3+ Hero (right) in (a) underwater housings with (b) additional battery packs for flash (Nikon) and video light (GoPro) (c), and (d) external screen (only GoPro). / Nikon D300 (izquierda) y GoPro 3+ Hero (derecha) en (a) estuches subacuáticas con (b) baterías adicionales para flash (Nikon) y luz de vídeo (GoPro) (c), y (d) pantalla externa (solo GoPro).
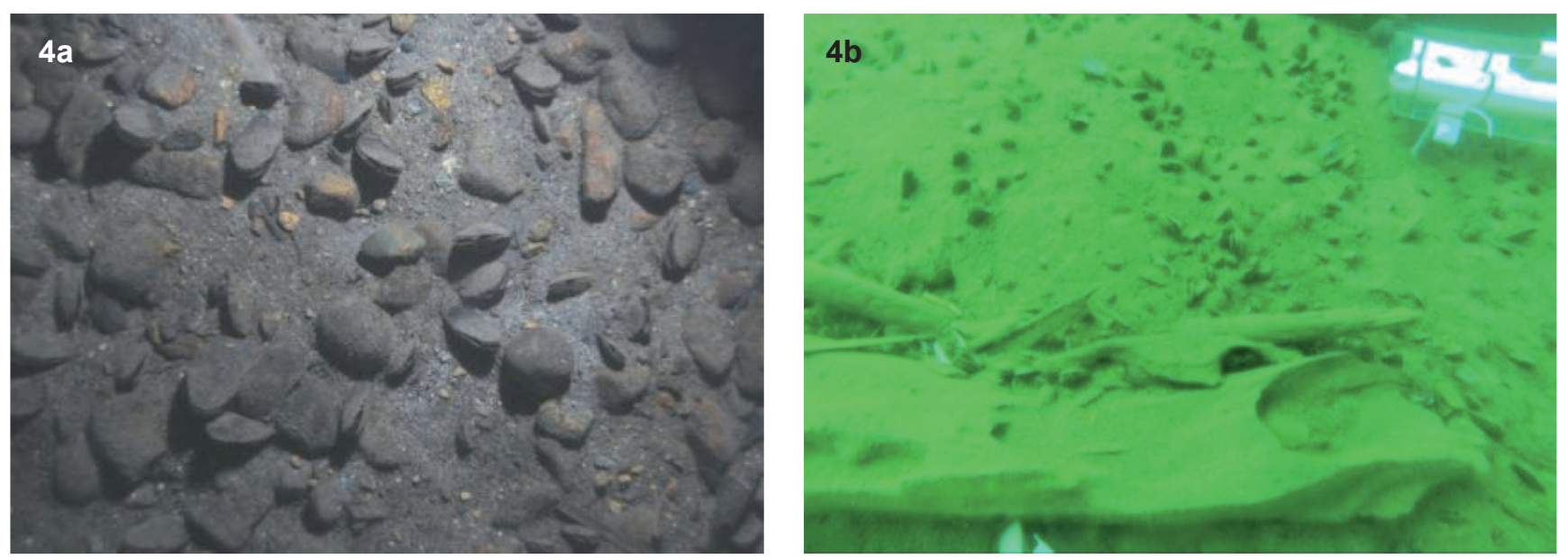

FiguRE 4. Original image section of the Nikon camera (a) and the GoPro camera (b). / Sección de imagen original de la cámara Nikon (a) y GoPro. 
TIME LAPSE SETTING

Both cameras were programmed to take one picture at a defined interval in the highest definition possible for each camera (Nikon D300 12.1 Megapixels; GoPro 12 Megapixels). During the fieldwork phase in 2015 both, the Nikon and the GoPro camera, were programmed to trigger once per minute. In 2016 we changed the time lapse interval of the Nikon camera to one image per 2 minutes, the GoPro stayed in the 1 minute interval. The difference in the time intervals emerges from the technical options of both cameras. The Nikon camera allows any desired time interval, whereas the GoPro can only be programmed at fixed time intervals between 0.5 and $60 \mathrm{sec}(0.5 \mathrm{sec}, 1 \mathrm{sec}$, $2.5 \mathrm{sec}, 30 \mathrm{sec}$ or $60 \mathrm{sec})$. The cameras were installed and recovered in the required depth by Scuba diving (Fig. 5). For imaging both camera systems were used simultaneously in the same depth, in a distance of approximately $10 \mathrm{~m}$ between them.

Data ANALYSIS

The analysis of the exhalant siphon area was done by the help of the computer program "Fiji" (version v1. 50i) (Schindelin et al. 2012). Time lapse series images were loaded in the program and for each analyzed mussel the exhalant siphon area (ESA) (Fig. 6) was measured in every single image and expressed as the percentage of the maximum opening of the analyzed individual (Newell et al. 2001; Riisgård et al. 2003) (Fig. 7).

Two of the time lapse series (one with flash light and one with permanent light) recorded in March 2015 were analyzed with regard to the abundance of the freshwater crab Aegla abtao over time. The recording started at $7 \mathrm{pm}$, included the sunset (8:01 pm local time) and stopped at 10:30 pm. The area of the frame on which the Nikon- camera was fixed was $0.12 \mathrm{~m}^{2}$, whereas the GoPro camera captured an area twice as large $\left(0.24 \mathrm{~m}^{2}\right)$. In each image the individual number of Aegla abtao was counted and extrapolated to $1 \mathrm{~m}^{2}$.

\section{RESULTS}

IN SITU FILTRATION ACTIVITY

Within a period of seven days a total of 14 time lapse series of Diplodon chilensis were recorded at different times of the day in March 2016, nine with the Nikon D300 and five with the GoPro camera. In every single time lapse series 5-16 adult individuals of $D$. chilensis were analyzed. Only those individuals were chosen that were embedded nearly perpendicularly and whose exhalant siphon area was clearly visible. In total 154 specimens were analyzed. Longest recording time was $13.5 \mathrm{~h}$. Altogether 19,155 data points in form of exhalant siphon areas were recorded and measured. To evaluate how much of the day time $D$. chilensis is filtering e.g. with a nearly completely opened exhalant siphon or completely stops water pumping activity (and several grades in between: up to $25 \%, 50 \%$ and $75 \%$ opened siphon) all measured data were pooled together and calculated as percentages of the total recording time. A totally closed siphon was observed during $3.4 \% \pm 5.2 \%$ of the recording time. An ESA between $0 \%$ and $25.0 \%$ could be observed during $2.9 \% \pm 5.1 \%$ of the day and between $25.1 \%$ and $50.0 \%$ during $10.0 \% \pm 12.1 \%$ of the day. Most of the day time the siphon was opened $50.1 \%-75.0 \%$ for

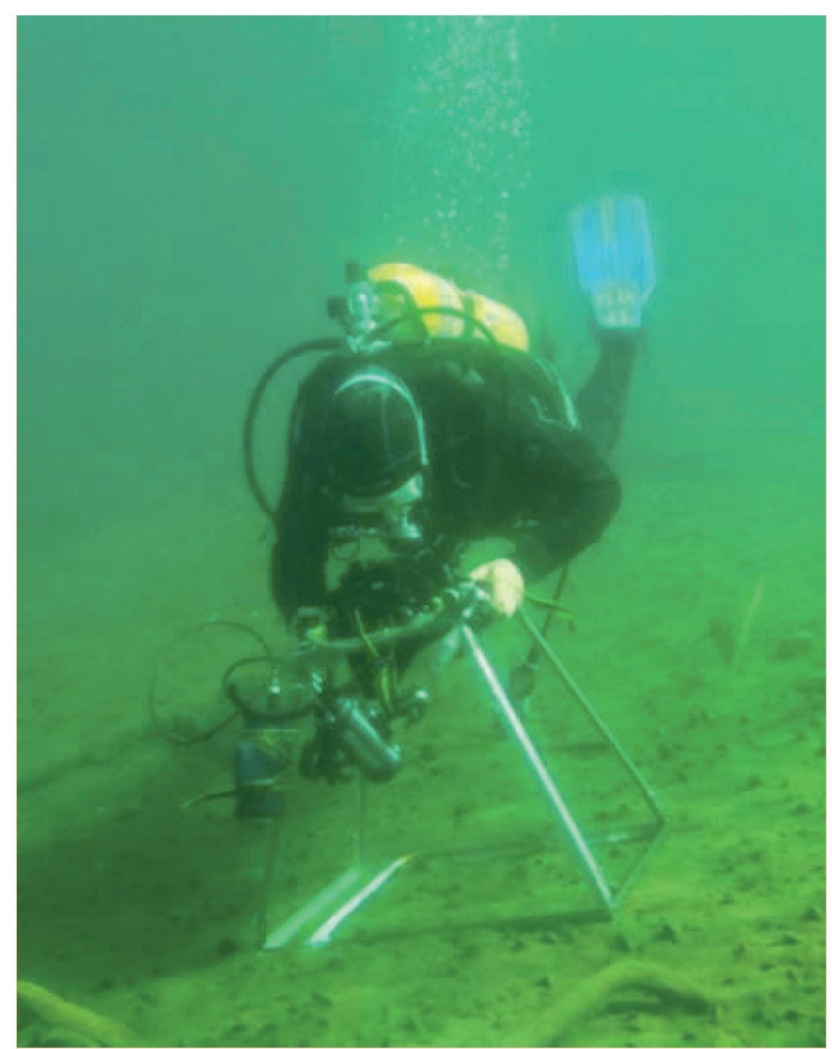

Figure 5. SCUBA diver installing the Nikon camera over a D. chilensis bed. / Buzo autónomo instalando la cámara Nikon encima de zona de D. chilensis.

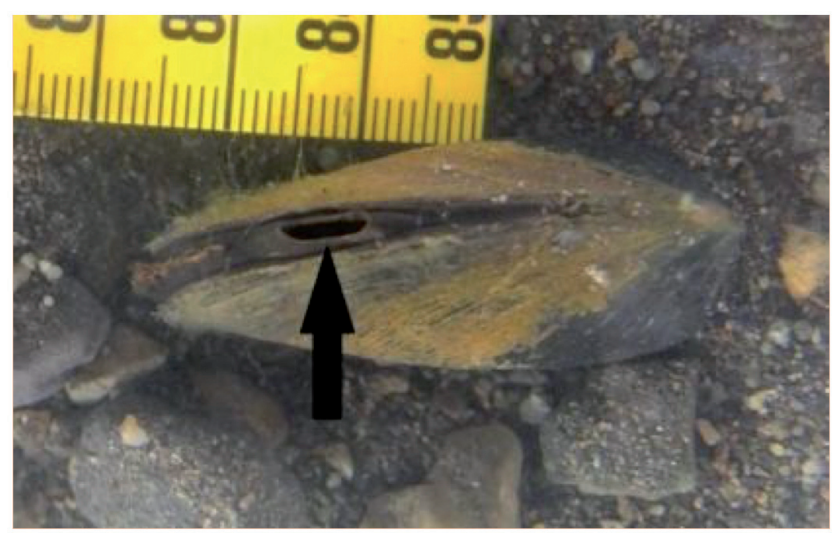

Figure 6. Exhalant siphon of D. chilensis (tip of arrow). / Sifón exhalante de D. chilensis. 
$41.1 \% \pm 17.1 \%$ of the time and was nearly completely opened $(75.1 \%-100.0 \%)$ during $42.7 \% \pm 22.9 \%$ of the day time (Fig. 8). Considering all data of the Nikon and the GoPro the mean siphon opening was $68.3 \% \pm 26.5 \%$.

FLASH LIGHT VS. VIDEO LIGHT

All images of the late evening- time lapse series were analyzed with regard to the number of the crustacean Aegla abtao to estimate whether the mobile fauna, especially the mentioned predator of $D$. chilensis, was attracted and therefore $D$. chilensis might indirectly be affected by the permanent illuminating video light of the GoPro camera that we used in parallel to the flash light of the Nikon camera. Both cameras were installed in a distance of $10 \mathrm{~m}$ assuming the flash light area was not influenced by the permanent illuminating video lights and vice versa. Data are summarized in time intervals of half hours (Fig. 9).
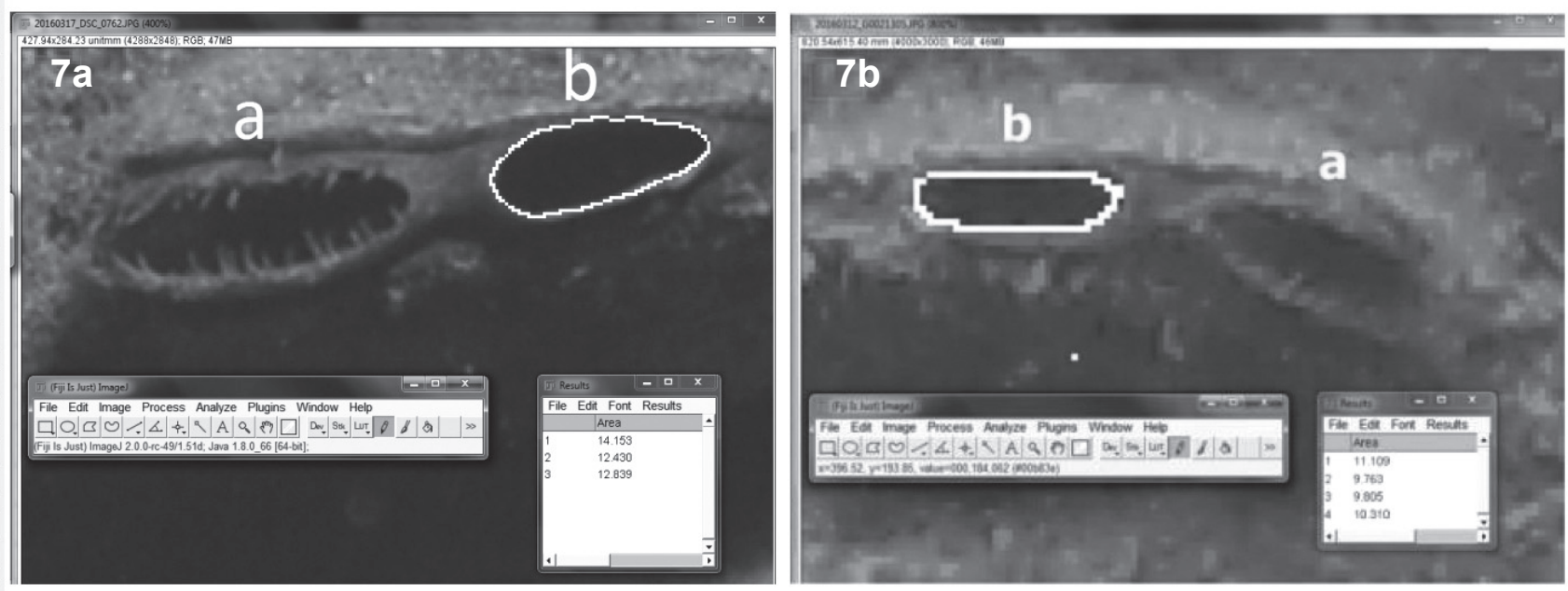

FIGURE 7. Screenshot of the Fiji interface, showing two analyzed images (7a: Nikon, 7b: GoPro), encircled exhalant siphon area (white line), tool bar and result list with measured areas; a: inhalant siphon, b: exhalant siphon. / Captura de pantalla de la interfaz de Fiji, que muestra dos imágenes analizadas (7a: Nikon, 7b: GoPro), área de sifón exhalante rodeado (línea blanca), barra de herramientas y lista de resultados con áreas medidas; a: sifón inhalante, b: sifón exhalante.

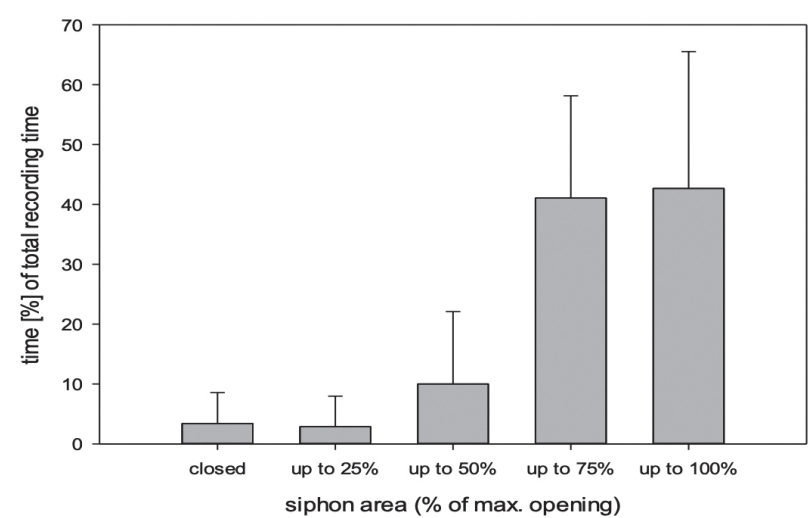

FiguRE 8. Percentage of total recorded time for different degrees of exhalant siphon area (ESA) of $D$. chilensis $(\overline{\mathrm{x}} \pm 1 \mathrm{SD})$; data base on analysis: $\mathrm{n}=154$ individuals. / Porcentaje del tiempo total registrado para diferentes grados de área de sifón exhalante (ESA) de $D$. chilensis $(\overline{\mathrm{x}} \pm 1 \mathrm{SD})$; base de datos sobre el análisis: $\mathrm{n}=154$ individuos.

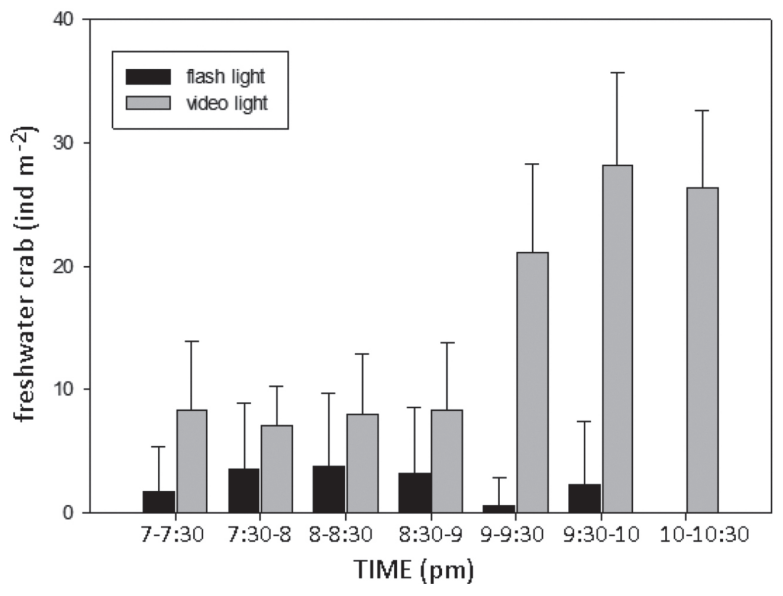

FIGURE 9. Number of freshwater crab Aegla abtao individuals $\mathrm{m}^{-2}$ (mean $\pm 1 \mathrm{SD}$ ) present in areas with Nikon-flashlight (black bars) and permanent video light of the GoPro (grey bars) during late evening (7 - 10:30 pm). / Número de individuos de Aegla abtao $\mathrm{m}^{-2}$ (media $\pm 1 \mathrm{SD}$ ) presentes en áreas con linterna Nikon (barras negras) y luz de vídeo permanente del GoPro (barras grises) durante la noche (7 - 10:30 pm). 
On flash light influenced areas the number of Aegla individuals was low rising slightly from $1.7 \pm 3.7$ ind. $\mathrm{m}^{-2}$ in the evening (7:00-7:30 pm) to its maximum of $3.8 \pm 5.8$ ind. $\mathrm{m}^{-2}(8: 00-8: 30 \mathrm{pm})$ and again decreasing towards later evening $\left(2.3 \pm 5.1\right.$ ind. $\left.\mathrm{m}^{-2}\right)$ at 9:30-10:00 $\mathrm{pm}$ and even zero individuals at night (10:00-10:30 pm) (Fig. 9). Areas illuminated by permanent light showed a much higher number of Aegla individuals in comparison to flash light affected areas (Fig. 10). Between 07:00 pm and 9:00 pm individual numbers are around $7.9 \pm 4.7$ ind. $\mathrm{m}^{-2}$. Then a leap in the data is detectable and the number of Aegla individuals rises to $21.1 \pm 7.2$ ind. $\mathrm{m}^{-2}$ at 9:00-9:30 pm, reaching a maximum of $28.2 \pm 7.4$ ind. $\mathrm{m}^{-2}$ at 9:30-10:00 pm (Fig. 9).
The mean value over the observation time is $2.5 \pm 4.8$ ind. $\mathrm{m}^{-2}$ for the flash light areas and $14.9 \pm 10.4$ ind. $\mathrm{m}^{-2}$ for the permanently illuminated areas.

\section{DATA ACCURACY}

The cameras were programmed to trigger every 2 minutes (Nikon) or 1 minute (GoPro). In the latter case only every second image was used for the calculations done with regard to the exhalant siphon area in this study. Different time intervals ( $2 \mathrm{~min}, 4 \mathrm{~min}, 8 \mathrm{~min}$, and $16 \mathrm{~min}$ ) were checked whether and to what extent the data remain reliable. In all cases the overall mean ESA value and its standard deviation remained nearly the same regardless of the chosen time interval (mean ESA: min. $68.04 \%$ for 16 min interval and max. $68.43 \%$ for 4 min interval) (Table 2, Fig. 11).

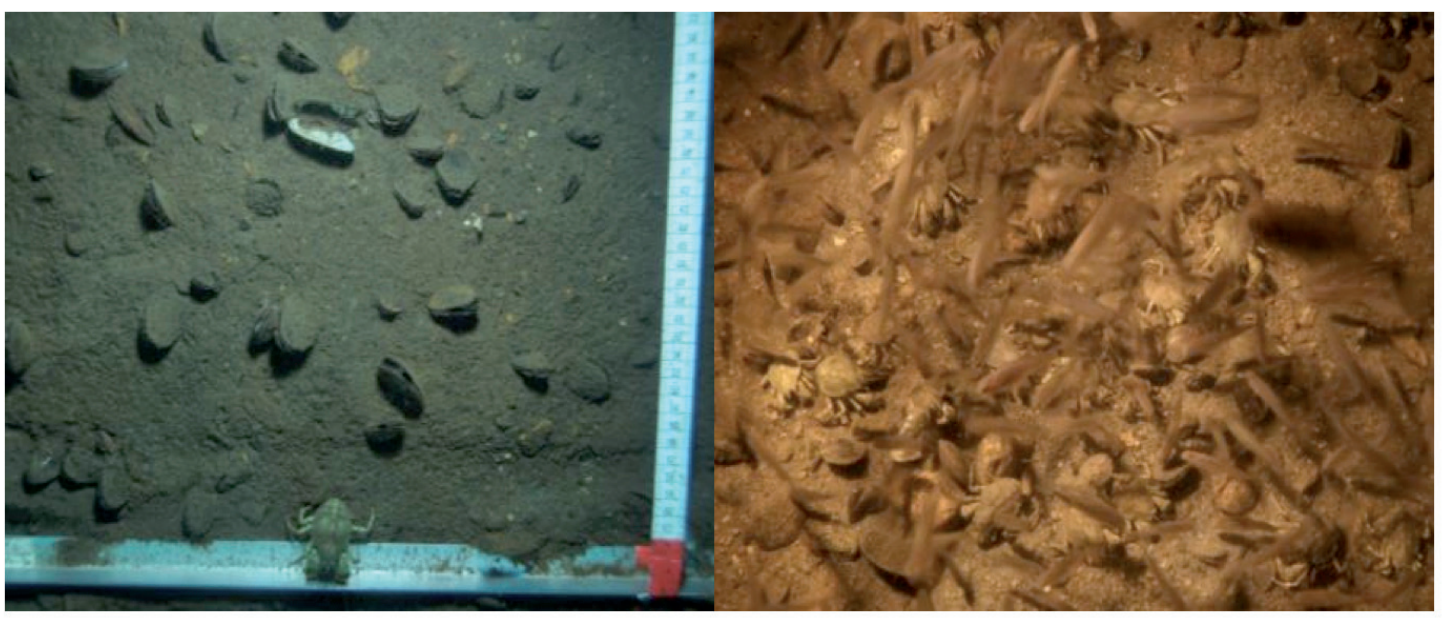

FIGURE 10. Effect of flash light (a) and of permanent light (b) on mobile fauna like fishes and the freshwater crab Aegla abtao; both images are taken at approximately $11 \mathrm{pm}$. / Efecto de la luz de destello (a) y de la luz permanente (b) en la fauna móvil como los peces y el cangrejo de agua dulce Aegla abtao; ambas imágenes tomadas aproximadamente a las 23:00 hrs.

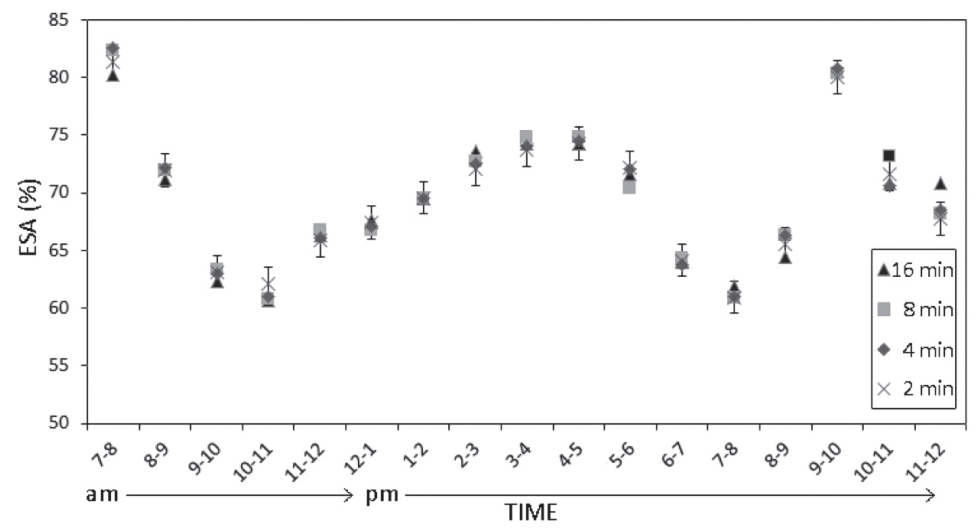

FIGURE 11. Changes in the mean exhalant siphon area in relation to day time using different time lapse intervals. / Cambios en el área media del sifón exhalante en relación con el tiempo diurno usando diferentes intervalos de tiempo. 
TABLE 2. Comparison of overall mean ESA and relative standard deviation (percentage of mean) when images are evaluated at different time intervals. / Comparación de la media total ESA y la desviación estándar relativa (porcentaje de la media) cuando las imágenes se evalúan en diferentes intervalos de tiempo.

\begin{tabular}{cccc}
\hline TIME LAPSE INTERVAL & $\begin{array}{c}\text { mean ESA } \\
{[\%]}\end{array}$ & $\begin{array}{c}\text { SD } \\
{[\%]}\end{array}$ & NUMBER OF ANALYZED IMAGES \\
\hline 16 min & 68.04 & 26.61 & 2356 \\
8 min & 68.42 & 26.3 & 4785 \\
4 min & 68.43 & 26.37 & 9598 \\
2 min & 68.33 & 26.46 & 19155 \\
\hline
\end{tabular}

\section{DISCUSSION}

\section{TECHNICAL ASPECTS}

Our data clearly showed that in general both cameras performed well under in situ conditions during day time. However, the low-cost GoPro camera revealed some particular limitations. It has a fixed wide-angle lens which cannot be armed with other kind of lenses when using a standard housing. Therefore, the images cover a wide range of the sediment (Fig. 4) when applied at the same distance as the Nikon camera. This causes a distortion of the image, which makes accurate measurements at the periphery impossible, because the image becomes blurred quite soon in the edge parts. When zooming into the image for analyzing the exhalant siphon areas, the image quality decreases significantly in comparison to images taken by the Nikon camera (Fig. 7). As D.chilensis is a quite large species and the siphon easily visible, this is not such a problem in our study, but might be one in the case of smaller animals like the common freshwater mussel Dreissena polymorpha (not present in Chile), other small mussels $(<15 \mathrm{~mm})$ such as those of the genus Pisidium and Sphaerium between others which are common in Chile (Parada and Peredo 2006) and small D. chilensis (e.g. juveniles) which live generally buried in the sediment.

In order to apply the presented methodological approach, it is very important to generate high quality images of $D$. chilensis in order to distinguish the exhalent siphons from pseudosiphons since adults expose both posterior edge and the pseudosiphons to feed in gravel (Yusseppone et al. 2017).

With respect to the battery capacities, both cameras and lightings have to be improved. It is not possible to record time lapse series over a couple of days or even for a complete day-night cycle. This means external battery packs have to be placed in external underwater housings and connected to the cameras and lights. The Nikon camera and its housing have a more robust appearance, but this comes along with a higher weight and bulkier size. The GoPro instead is quite small and can be used e.g. for in-aquaria recordings. The right choice of the camera system should be always related to the experimental design; no general recommendation can be given apart from the suggestion to check carefully that the battery capacity is not limiting the study.

The slightly inclined position of the GoPro camera towards the ground and therefore to the recorded bivalves does not have an effect on the determination of the exhalant siphon area, as the animals normally stay at their location. So the magnifying effect is the same for all evaluated images of one single animal. For further calculation only relative values are used (\% of the maximum siphon opening) and so remain comparable to ESA-values of other individuals of the time lapse series.

FLASH LIGHT VS. VIDEO LIGHT

The permanent lighting of the GoPro camera attracted much more mobile fauna than the flash light of the Nikon camera, although we used a red foil to reduce light emission as done by others (Turra and Denadai 2003). For further time lapse recordings, the red filter of the permanent light has to be optimized or completely be replaced by a flash or lamp that only emits light when the camera is taking the photo. Apart from the freshwater crab Aegla abtao, a lot of small fishes were visible in the analyzed images, but were not further considered, as they do not touch the bivalves and are therefore not supposed to disturb. Different with the A.abtao individuals, that walked around the mussels and might influence the filtration behavior and the distribution of the mussels. The later the evening, on the flash light area the number of $A$. abtao decreased, while on the permanent light area the number increased. A too large physical proximity of the two cameras can be excluded as higher densities (2030 ind. $\mathrm{m}^{-2}$ ) were only found at the permanent illuminated area. Lara and Moreno (1995) found that this freshwater crab preys on $D$. chilensis and showed that these mussels are sensitive to the contact of A.abtao. Therefore, the use of 
permanent light sources is not recommended for time series of D. chilensis as they attract one of its natural predators and alter its filtration activity.

Another aspect of the influence of the permanent light source is related to the enhanced presence of many small fishes and zooplankton (Daphnia, copepods) during night. This interferes when analyzing the images and hampers the proper interpretation of the ESA. Especially for the night recordings an improvement of the illumination is necessary, as the data of the Aegla densities at night with different types of lighting showed (Fig. 9, Fig. 10).

The advantage of this non invasive method as we used in this study is, that the animals are observed in their natural habitat without touching them in any way. The only interference might be the dispersion of sediment when the camera is positioned and the light or flash light emission of the camera. In laboratory experiments Riisgård et al. (2003) also used time lapse techniques and monitored the opening degree of siphons of the cockle Cerastoderma edule and the sand clam Mya arenaria during clearance experiments by recording the movements with a video camera (Sony CCDV700E) which was placed above the experimental aquarium.

\section{FiLTERING ACTIVITY OF DIPLODON CHILENSIS}

Time lapse photography allows to take a huge number of images in very short time intervals detecting rapid changes caused by disturbance, sun set or other factors. Comparing different time intervals $(2,4,8,16 \mathrm{~min})$ in our study demonstrated that the results did not change when increasing the interval time from 2 to $16 \mathrm{~min}$ (Fig. 11).

Until now there were no data available on the filtration activity patterns of the Chilean fresh water clam Diplodon chilensis under in situ conditions. Therefore, it is not possible to compare our data directly to those of other authors and this study can be considered as the first analyzing of the filtration activity of $D$. chilensis over a longer time period and in a non- invasive way by time lapse recording. However, there exists similar information on other bivalve species under experimental conditions.

Higgins (1980) studied the valve opening of Crassostrea virginica and showed that continuously fed oysters were open for about $94 \%$, whereas unfed animals were open only about $35 \%$ of the recorded time. With $90 \%$ opening time Jørgensen (1966) reported similar values for C. virginica. Mya arenaria (a completely buried clam species, only siphons reach the sediment surface) had their siphons open approximately $85 \%$ of the submersion time during a tidal cycle. During the opened status the individuals have the two siphons open and do not show any apparent movement. The most frequent events are simultaneous closing followed by simultaneous opening of the two siphons (Thorin et al. 1998). The filtration behavior of the blue mussel Mytilus edulis was studies by Loosanoff (1942) who found the valves of this species to be opened for $97 \%$ to $99 \%$. In the latter mentioned studies the siphon and valve opening is only subdivided into the status opened or closed, whereas our data of the freshwater clam Diplodon chilensis are separated in various opening states (Fig. 8). A totally closed siphon can be observed for $3.4 \% \pm 5.2 \%$ of the recorded time, this means for the vast majority of the time the exhalant siphon is at least a little bit opened and the animals are pumping water. The mean siphon opening is $68.3 \% \pm 26.5 \%$ (Tabla 2). Having a closer look at our raw data of the analyzed animals, these also exhibit specimens which have their shells closed for almost the entire recording time while others next to them show overall a more opened status. This might be one explanation for the high standard deviations of the overall ESA values (Tabla 2).

The inhalant and exhalant siphons of Donax vittatus are described to be open for nearly $100 \%$ of the observation time. Only in periods of wave disturbance or after local disturbances or preceding pseudofaeces ejections siphons are closed, but only for time spans shorter than 1 minute (Ansell 1994). Foster-Smith (1976) showed that for minor reductions of the siphon opening, the water volume pumped per minute is not influenced and the flow speed of the water increases while the pumping rate remains the same. He estimated that the exhalant siphon aperture has to be reduced by $80 \%$ to notice an effect on the total water volume flowing through a bivalve. But not only abiotic factors like temperature etc. but also particle concentration and composition are essential factors that determine bivalve filtration activity (Cranford 2001; Widdows 2001). However, this was not the main objective of this study, but will be investigated in more detail in another study on this topic.

Our study confirmed, that time lapse series are an adequate way of studying filtering animals in the field even if they can never completely replace measurements of mussel filtration rates, using direct or indirect methods.

\section{ACKNOWLEDGEMENTS}

This work was supported by the International Bureau, Bonn, FRG.

\section{REFERENCES}

Ansell, A.D. 1994. In situ activity of the sandy beach bivalve Donax vittatus (Bivalvia Donacidae) in relation to potential predation risks. Ethology Ecology \& Evolution 6(1):43-53.

Atkinson, C.L., Vaughn, C.C., Forshay, K.J., Cooper, J.T. 2013. Aggregated filter-feeding consumers alter nutrient limitation: consequences for ecosystem and community dynamics. Ecology 94: 1359-1369.

Atkinson, C.L., Vaughn, C.C. 2015. Biogeochemical hotspots: 
temporal and spatial scaling of the impact of freshwater mussels on ecosystem function. Freshwater Biology 60: 563-574.

Barahona, M., Navarrete, S.A. 2010. Movement patterns of the seastar Heliaster helianthus in central Chile: relationship with environmental conditions and prey availability. Marine Biology 157(3):647-661.

BAYNE, B.L. 1998. The physiology of suspension feeding by bivalve molluscs: an introduction to the Plymouth 'TROPHEE' workshop. Journal of Experimental Marine Biology and Ecology 219: 1-19.

Beuchelm, F., Primicerio, R., Lønne, O.J., Gulliksen, B., Birkely, S. 2010. Counting and measuring epibenthic organisms from digital photographs: A semiautomated approach. Limnology and Oceanography: Methods 8:229-240.

Carey, F.J., Pettengill, O.S. 1967. A time-lapse study of effects of anticellular antibody on membrane mobility and phagocytic activity of HeLa cells. The Journal of cell biology 33(3), 33(3):709-712.

CRANFord, P.J. 2001. Evaluating the 'reliability' of filtration rate measurements in bivalves. Marine Ecology Progress Series 215:303-305.

DAVENPORT, J. 1979. The isolation response of mussels Mytilus edulis $L$. exposed to falling seawater concentrations. Journal of the Marine Biological Association UK 59:123132.

Fedra, K., Machan, R. 1979. A self-contained underwater timelapse camera for in situ long-term observations. Marine Biology 55(3):239-246.

Higgins, P.J. 1980. Effects of food availability on the valve movements and feeding behaviour of juveniles Crassostrea virginica (Gmelin): 1. Value movements and periodic activity. Journal of Experimental Marine Biology and Ecology 45:229-244.

Jørgensen, C.B. 1966. Biology of Suspension Feeding. Pergamon Press, Oxford, 357 p.

Jørgensen, C.B. 1996. Bivalve filter feeding revisited. Marine Ecology Progress Series 142: 287-302.

KOHLER, S.L. 1984. Search mechanism of a stream grazer in patchy environments: the role of food abundance. Oecologia 62:209-218.

Kramer, K.J, Jenner, H.A., deZwart, D. 1989. The valve movement response of mussels: a tool in biological monitoring. Hydrobiologia 188:433-443.

Lampitt, R.S., Rice, A.L., Thurston, M.H. 1984. The use of in situ photography in studies of the deep sea benthos at IOS Institute of Oceanographic studies. Natural Environment Research Council, Surrey. No. 182, 39pp.

Lara, G., Parada, E. 1988. Distribución espacial y densidad de Diplodon chilensis chilensis (Gray, 1928) (Mollusca: Bivalvia) en el Lago Villarrica. Boletín de la Sociedad de Biología de Concepción 58:105-114.

Lara, G., Moreno, C. 1995. Efectos de la depredación de Aegla abtao ( Crustacea, Aeglidae) sobre la distribución espacial y abundancia de Diplodon chilensis (Bivalvia, Hyriidae) en el Lago Panguipulli, Chile. Revista Chilena de Historia Natural. 68: 123-129.

Lara, G., Contreras, A., Encina ,F. 2002. La almeja de agua dulce Diplodon chilensis (Bivalvia: Hydriidae) potencial biofiltro para disminuir los niveles de coliformes en pozos.
Experimentos de laboratorio. Gayana 66(2): 113-118.

Lara, G., Parada, E. 2008. Mantencion del patron de distribucion espacial, densidad y estructura de tamaños de la almeja de agua dulce Diplodon chilensis Gray, 1828 (Bivalvia: Hyriidae) en el lago Panguipulli, Chile. Gayana 72(1): 4551.

Loosanoff, V.L. 1942. Shell movements of the edible mussel, Mytilus edulis (L.) in relation to temperature. Ecology 23(2):231-234.

Manley, A.R. 1983. The effects of copper on the behaviour, respiration, filtration and ventilation activity of Mytilus edulis. Journal of the Marine Biological Association UK 63:205-222.

MarX, R.F. 1990. The History of Underwater Exploration. Courier Corporation. Dovers publications, Inc., New York. 198pp.

Mitchell, C.T. 1967. An inexpensive self-contained underwater data recording camera. California Fish and Game 53:203208.

Newell, C.R., Wildish, D.J., MacDonald, B.A. 2001. The effects of velocity and seston concentration on the exhalant siphon area, valve gape and filtration rate of the mussel Mytilus edulis. Journal of Experimental Marine Biology and Ecology 262(1):91-111.

Parada, E., Peredo, S. 2005. La relocalización como una herramienta de conservación y manejo de la biodiversidad: Lecciones aprendidas con Diplodon chilensis (Gray 1828) (Bivalvia, Hyriidae). Gayana 69(1):41-47.

Parada, E., Peredo, S. 2006. Current state of knowledge of freshwater bivalves of Chile. Gayana 70 (1):82-87.

Parada, E., Peredo, S., Valenzuela, J., Manuschevich, D. 2007. Extention of the current northern distribution range of freshwater mussel Diplodon chilensis (Gray, 1828) (Bivalvia: Hyriidae) in Chile. Gayana 71(2):212-215.

RIISGÅRD, H.U. 2001. On measurement of filtration rates in bivalves - the stony road to reliable data: review and interpretation. Marine Ecology Progress Series 211: 275-91.

RiIsgård, H.U., Kittner, C., Seerup, D.F. 2003. Regulation of opening state and filtration rate in filter-feeding bivalves (Cardium edule, Mytilus edulis, Mya arenaria) in response to low algal concentration. Journal of Experimental Marine Biology and Ecology 284:105-127.

Sabatini, S.E., Rocchetta, I., Luquet, C.M., Guido, M.I., Ríos DE Molina, M.C. 2011. Effects of sewage pollution and bacterial load on growth and oxidative balance in the freshwater mussel Diplodon chilensis. Limnologica 41: 356-362.

Sawyer, J.A., Zuschin, M., Riedel, B., Stachowitsch, M. 2009. Predator-prey interactions from in situ time-lapse observations of a sublittoral mussel bed in the Gulf of Trieste (Northern Adriatic). Journal of Experimental Marine Biology and Ecology 371(1):10-19.

Schindelin, J., Arganda-Carreras, I., Frise, E., Kaynig, V., Longair, M., Pietzsch, T., Preibisch, S., Rueden, C., SaAlfeld, S., Schmid, B., Tinevez, J., White, D.J., Hartenstein, V., Eliceiri, K., Tomancak, P., Cardona, A. 2012. Fiji: an open-source platform for biological-image analysis. Nature methods 9(7):676-682.

Soldati, A.L., Jacob, D.E., Schöne, B.R., Bianchi, M.M., HajduK, A. 2009. Seasonal periodicity of growth and composition in valves of Diplodon chilensis patagonicus (d'Orbigny, 
1835). Journal of Molluscan Studies 75(1):75-85.

Soto, D., Mena, G. 1999. Filter feeding by the freshwater mussel, Diplodon chilensis, as a biocontrol of salmon farming eutrophication. Aquaculture 171(1-2): 65-81.

Stachowitsch, M., Riedel, B., Zuschin, M., Machan, R. 2007. Oxygen depletion and benthic mortalities: the first in situ experimental approach to documenting an elusive phenomenon. Limnology and Oceanography: Methods 5(10):344-352.

Thorin, S., Bourdages, H., Vincent, B. 1998. Study of siphon activity in Mya arenaria (L.) in the intertidal zone by means of an underwater video camera. Journal of Experimental Marine Biology and Ecology 224(2):205-224.

Turra, A., Denadai, M.R. 2003. Daily activity of four tropical intertidal hermit crabs from southeastern Brazil. Brazilian Journal of Biology 63(3):537-544.
Valdovinos, C., Pedreros, P. 2007. Geographic variations in shell growth rates of the mussel Diplodon chilensis from temperate lakes of Chile: Implications for biodiversity conservation. Limnologica. 37:63-75.

Vaughn, C.C. 2018. Ecosystem services provided by freshwater mussels. Hydrobiologia 810 (1): 15-27.

WidDows, J.2001. Bivalve clearance rates: inaccurate measurements or inaccurate reviews and misrepresentation? Marine Ecology Progress Series 221:303-305.

Woelfl, S. 2007. The distribution of large mixotrophic ciliates (Stentor) in deep North Patagonian lakes (Chile): first results. Limnologica 37: 28-36.

Yusseppone, M. S., Márquez, F., Luquet, C. M., Brey, T., Ríos de Molina, M. C., Rocchetta, I. 2018. Does shell shape variation play a role in conservation of the long lived freshwater bivalve Diplodon chilensis (Bivalvia, Hyriidae)? Ecohydrology 11(2): e1931.

Recibido: 22.01 .2018

Aceptado: 22.01.2019 